16 a 18 de outubro de 2019 - Campinas | Brasil

\title{
Em busca da memória dos cinemas de rua: o Cine Recreio
}

\section{Carolina Ferreira Pieroni*}

\section{Resumo}

Este trabalho busca contar a história dos cinemas de rua da cidade de São Sebastião do Paraíso, localizada no estado de Minas Gerais no Brasil. Essa história começa em 1906 e continua até hoje, esta pesquisa foca em um destes cinemas, chamado Cine Recreio, que funcionou de 1920 até o fim dos anos 70, mas também apresenta outras salas que existiram e que continuam funcionando na cidade atualmente. Esta pesquisa foi realizada a partir de documentos da época, em sua maioria jornais impressos preservados, além de entrevistas com pessoas que vivenciaram o período de funcionamento do Cine Recreio, algumas delas ex-funcionárias da sala. Este trabalho mescla dados documentais com relatos pessoais e, assim, constrói e resgata a memória dos cinemas de rua numa cidade do interior do Brasil.

\section{Palavras-chave: \\ cinema, Cine Recreio, São Sebastião do Paraíso}

\section{Introdução}

E este artigo se desenvolve a partir de uma proposta de resgate e preservação da sala conhecida como Cine Recreio, um dos cinemas de rua da cidade de São Sebastião do Paraíso-MG. A inspiração inicial para esta pesquisa reside em histórias contadas por meu avô, que trabalhou neste cinema em sua infância.

São Sebastião do Paraíso sempre foi pequena e interiorana. Mesmo assim, ao longo do século XX, sua população desfrutou de duas salas de cinema de rua possuía dois cinemas de rua que costumavam estar lotados. Os habitantes de São Sebastião do Paraíso são muito orgulhosos da cultura cinematográfica de sua cidade, e por isso existem livros e reportagens de jornal que alimentaram a presente pesquisa, assim como relatos dos próprios moradores. Graças a uma razoável quantidade de informações pude resgatar estas memórias e debate-las neste artigo.

\section{Resultados e Discussão}

O Cine Recreio foi a terceira experiência com exibição cinematográfica na cidade de São Sebastião do ParaísoMG, que começou em 1906. A primeira experiência foi em num barracão improvisado que exibia filmes com um projetor a dínamo, mas o espaço pegou fogo por conta do superaquecimento da tela, À mesma época existiu o Cine Biju, que foi comprado na década de 20 pelo imigrante italiano Pedro Fressatti. Logo após adquirir o Cine Biju, Fressatti mudou a sala de endereço e rebatizou-a como Cine Recreio ${ }^{1}$.

O Cine Recreio era gerenciado pela família Fressatti, que morava no próprio prédio do cinema. Cada membro da família possuía uma na administração do negócio, desde a projeção até a propaganda. ${ }^{2}$ Por conta do assassinato de um dos filhos do Sr. Fressatti, em 1938, e, posteriormente, de um acidente com outro de seus filhos, a família se reorganizou para continuar administrando a sala. Em 1950 o Sr. Fressatti, endividado, se afastou da gerência do Cine Recreio, que foi assumida por seu genro, Geraldo Pieroni, outro imigrante italiano. ${ }^{3}$ Pieroni renovou a aparelhagem do cinema e o modernizou, porém essa fase não durou muito tempo. Entre 1956 e 58 a família Fressatti decidiu vender o Cine Recreio para um empresário alemão que já havia comprado a outra sala de cinema da cidade, o Cine São Sebastião. ${ }^{3}$

Mesmo após a venda, os dois cinemas se mantiveram em funcionamento até quase os anos 80 , quando então ambos faliram. $O$ prédio onde era localizado 0 Cine
Recreio foi demolido e em seu lugar foi construído um prédio residencial: $\mathrm{O}$ Edifício Recreio.?

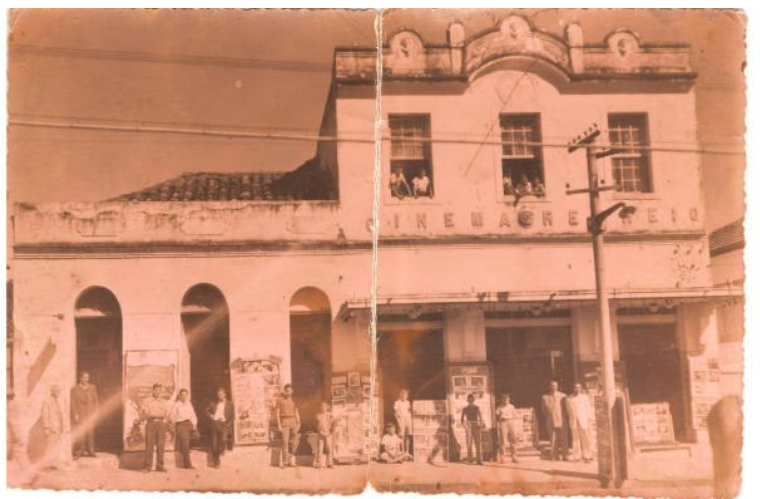

Figura 1. Fachada do cinema de rua Cine Recreio em meados de 1950.

\section{Conclusões}

Por causa da quantidade significativa de dados, houve divergências com respeito a algumas datas e nomes. Para contornar essa situação optei pelas informações que pareciam fazer maior sentido com as nãodivergentes, e que apresentavam um suposto maior valor documental, como os jornais e livros. Seguindo essa metodologia tracei a história do Cine Recreio, que mescla memórias com dados e oferece um contexto histórico da cultura cinematográfica da cidade de São Sebastião do Paraíso-MG.

\section{Agradecimentos}

Agradeço à Universidade Estadual de Campinas e ao meu orientador, Prof. Dr. Alfredo Suppia, por tornarem este trabalho possível. Agradeço também ao Programa Institucional de Bolsas de Iniciação Científica - PIBIC, sem o qual este artigo não teria sido feito. Finalmente, agradeço também ao meu avô, Renald Pieroni, que foi minha inspiração para este trabalho e à minha família, por terem me apoiado em cada etapa deste projeto.

${ }^{1}$ FERREIRA, Luiz. São Sebastião do Paraíso: História e Tradições. Ed. 1. São Paulo: Editora Resenha Tributária, 1975. 301 p.

${ }^{2}$ MACHADO, Harley Silva. O Cinema Recreio. Jornal do Sudoeste. São Sebastião do Paraíso. 24 out. 2015. Pag. 28. Disponível em: < http://www.jornaldosudoeste.com.br/noticia.php?codigo=108996>. Acesso em: 3 out. 2018

${ }^{3}$ PIERONI, Renald. Entrevista concedida a Carolina Ferreira Pieroni. Campinas, 21 out. 2018. 